\title{
Stimulated Tg level measurements may be avoided in differentiated thyroid carcinoma patients who have undetectable basal Tg levels
}

\author{
Ebuzer Kalender ${ }^{1}$, Umut Elboga ${ }^{1 *}$, Y.Zeki Celen ${ }^{1}$, Hasan Deniz Demir ${ }^{1}$, Ertan Sahin ${ }^{2}$, Seyhan Karaçavuş ${ }^{3}$, Mustafa Basibuyuk ${ }^{1}$ and \\ Mustafa Yilmaz ${ }^{1}$ \\ *Correspondence: umutelboga@hotmail.com \\ 'University of Gaziantep, School of Medicine, Department of Nuclear Medicine, Gaziantep, Turkey. \\ ${ }^{2}$ University of Namik Kemal, School of Medicine, Department of Nuclear Medicine, Tekirdag, Turkey. \\ ${ }^{3}$ University of Bozok, School of Medicine, Department of Nuclear Medicine, Yozgat, Turkey.
}

\begin{abstract}
Background: The aim of this retrospective study is to evaluate the diagnostic value of undetectable basal thyroglobulin (Tg) levels measured 6 months after ablative ${ }^{131}$ I treatment (AIT) in patients with differentiated thyroid carcinoma (DTC).

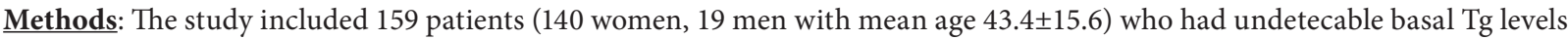
$(<0.2 \mathrm{ng} / \mathrm{ml})$ and negative anti-Tg antibodies, 6 months after AIT. Histologic examination was papillary thyroid carcinoma in 151 patients and follicular thyroid carcinoma in 8 patients. To control the AIT efficacy, diagnostic whole body scan (DWBS) was planned 6 months after AIT. Before DWBS, basal and stimulated Tg levels were measured and compared. Then all patients underwent DWBS.

Results: All patients (with undetectable basal Tg level) had a stimulated Tg level under $2 \mathrm{ng} / \mathrm{ml}$. Stimulated Tg levels were undetectable $(<0.2 \mathrm{ng} / \mathrm{ml})$ in $142(89.3 \%)$ patients and $0.58 \pm 0.26 \mathrm{ng} / \mathrm{ml}(\mathrm{range} 0.3-1.3 \mathrm{ng} / \mathrm{ml})$ in $17(10.7 \%)$ patients. The control DWBS, 6 months after thyroid ablation, was negative in 151 (95\%) patients and was positive for minimal residual uptake on the thyroid bed in $8(5 \%)$ patients. Stimulated Tg levels of patients with residual thyroid bed uptake on control DWBS, were undetectable $(<0.2 \mathrm{ng} / \mathrm{ml})$ in 4 patients and $0.8 \pm 0.19 \mathrm{ng} / \mathrm{ml}$ (range $0.3-1.3 \mathrm{ng} / \mathrm{ml})$ in 4 patients.

Conclusion: Our data suggest that stimulated Tg level measurements may be avoided in DTC patients with undetectable basal Tg levels. Thus, unnecessary Tg stimulation with rhTSH or endogen TSH, diagnostic procedures (DWBS) and radiation exposure can be reduced.
\end{abstract}

Keywords: Differentiated thyroid carcinoma, follow-up, thyroglobulin, diagnostic whole-body scan

\section{Introduction}

The large majority of patients with thyroid carcinoma have well differentiated tumors that are completely cured by surgery and thyroid ablation with radioiodine [1]. Lifelong follow-up of patients with diferentiated thyroid carcinoma (DTC) is important because recurrences may occur over time [2-4]. Thyroglobulin ( $\mathrm{Tg}$ ) measurements are the main tool in the management and follow-up of patients with DTC $[5,6]$. Serum Tg can be measured during thyroid hormone suppression therapy (basal Tg) or thyroid-stimulating hormone (TSH) stimulation with recombinant human TSH (rhTSH) or endogenously (stimulated Tg). Stimulated Tg measurement is more sensitive than the basal Tg measurement [7]. But the basal Tg measurement is important component of the follow-up. Basal Tg measurement using high-sensitive assays proved to be effective [8].

The aim of this retrospective study is to evaluate the diagnostic value of undetectable basal Tg levels measured 6 months after ablative ${ }^{131}$ I treatment (AIT) in patients with DTC.

\section{Methods}

One hundred and fifty-nine patients (140 women, 19 men with mean age $43.4 \pm 15.6$ years) who had undetecable basal Tg levels $(<0.2)$ and negative anti-Tg antibodies, 6 months after postsurgical radioablation treatment between January 2008 and January 2013 were selected for this retrospective study. Histologic examination revealed papillary thyroid carcinomas in 151 patients and follicular thyroid carcinomas in 8 patients.

Patients were treated by a total or near-total thyroidectomy followed by AIT, initially. Within a few months after surgery, patients were given $75-100 \mathrm{mCi}^{131} \mathrm{I}$ for remmant ablation after at least 3 week withdrawal of hormone therapy. A posttreatment ${ }^{131}$ I whole body scan (PWBS) was performed 5-10 days after AIT to all patients. To control the AIT efficacy, diagnostic whole body scan(DWBS) was planned 6 months after AIT. Before DWBS basal Tg levels and anti-Tg antibody levels were measured. Then patients discontinued taking thyroxine and followed a low-iodine diet during 3 weeks. Just before DWBS, stimulated $\mathrm{Tg}$ and anti-Tg antibody levels were measured when $\mathrm{TSH}>30 \mathrm{IU} / \mathrm{ml}$. Tg levels were measured using immunoradiometric analyzer that uses paramagnetic microparticles and chemiluminescent detection technology with a lower detection limit of $0.2 \mathrm{ng} / \mathrm{ml}$. After TSH stimulation, $5 \mathrm{mCi}(185 \mathrm{MBq}$ )

(C) 2013 Elboga et al; licensee Herbert Publications Ltd. This is an Open Access article distributed under the terms of Creative Commons Attribution License (http://creativecommons.org/licenses/by/3.0). This permits unrestricted use, distribution, and reproduction in any medium, provided the original work is properly cited. 
Kalender et al. Internal Medicine Inside 2013,

Table 1. Demographic and clinical features of all patients.

\begin{tabular}{lc}
\hline Age & $43.4 \pm 15.6$ \\
\hline Gender (M/F) & $19 / 140$ \\
\hline Pathology & \\
$\quad$ PTC & 151 \\
$\quad$ FTC & 8 \\
\hline Basal Tg (in all p., ng/ml) & $<0.2$ \\
\hline Stimulated Tg (ng/ml) & \\
$\quad$ in 142 p. $(89.3 \%)$ & $<0.2$ \\
$\quad$ in 17 p. $(10.7 \%)$ & $0.58 \pm 0.26$ \\
\hline DWBS & \\
$\quad$ positive & 8 \\
negative & 151 \\
\hline
\end{tabular}

PTC: Papillary thyroid carcinoma

FTC: Follicular thyroid carcinoma

Tg: Thyroglobulin

p: patient

DWBS: Diagnostic whole-body scan

${ }^{131}$ I was given orally to the patients and 2-3 days later, DWBS was performed to all patients.

During the follow-up, basal Tg and anti-Tg antibody levels were also measured in three month intervals. Statistical analysis and the calculations were performed using SPSS 11.0 for Windows. Differences were considered statistically significant at $\mathrm{P}<0.05$.

\section{Results and discussion}

After surgery, all patients underwent thyroid ablation with ${ }^{131} \mathrm{I}$, at doses ranging from $75-100 \mathrm{mCi}$, followed by PWBS. Thyroid remnants were present on PWBS in all patients and there was no foci of pathologic radioiodine uptake outside the thyroid bed. Six months later, all patients who had undetectable basal Tg levels, underwent the control DWBS and serum Tg measurement in the hypothyroid state. At this time, all patients had a stimulated Tg level under $2 \mathrm{ng} / \mathrm{ml}$. Stimulated Tg levels were undetectable $(<0.2 \mathrm{ng} / \mathrm{ml})$ in $142(89.3 \%)$ patients and $0.58 \pm 0.26 \mathrm{ng} / \mathrm{ml}$ (range $0.3-1.3 \mathrm{ng} / \mathrm{ml}$ ) in $17(10.7 \%)$ patients. The control DWBS, 6 months after thyroid ablation, was negative in 151 (95\%) patients and was positive for minimal residual uptake on the thyroid bed in $8(5 \%)$ patients. There was no statistically significant difference between patients that stimulated Tg levels were undetectable $(<0.2 \mathrm{ng} / \mathrm{ml})$ and detectable (range $0.3-1.3 \mathrm{ng} / \mathrm{ml}$ ) in the control DWBS findings $(P=0.32)$. No patient had scintigraphic or clinical evidence of local or distant metastases. Demographic and clinical features of patients are given in (Table 1).

Stimulated $\mathrm{Tg}$ levels of patients with residual thyroid bed uptake on control DWBS were undetectable $(<0.2 \mathrm{ng} / \mathrm{ml})$ in 4 patients and $0.8 \pm 0.19 \mathrm{ng} / \mathrm{ml}$ (range $0.3-1.3 \mathrm{ng} / \mathrm{ml}$ ) in the remaining 4 patients. The between of the patients that have undetectable and detectable Tg levels were not statistically significant for thyroid bed uptake on control DWBS.

Some imaging methods and laboratory tests are used on the follow-up of patients with DTC. Diagnostic whole body scan is one of the imaging methods. six-twelve months after thyroid ablation in the hypothyroid state, negative DWBS results with undetectable Tg levels are usually associated with complete remission [9]. In general, DWBS has a little help on the follow up DTC patients. Many studies have shown that the DWBS is almost no informative in patients who have undetectable stimulated Tg and negative anti-Tg antibodies [10-12]. On the other hand PWBS may detect new foci of tumor not seen on DWBS in up to $50 \%$ of patients $[13,14]$.

${ }^{18} \mathrm{~F}$-fluorodeoxyglucose-positron emission tomography (FDG-PET) can be useful in patients who have positive Tg level and negative radioiodine scan. An elevated serum $\mathrm{Tg}$ level $(>10 \mathrm{ng} / \mathrm{ml})$ with negative PWBS results is the main indication for ${ }^{18} \mathrm{~F}$-FDG PET $[15,16]$. ${ }^{18} \mathrm{~F}$-FDG PET also provides prognostic information. ${ }^{18} \mathrm{~F}-\mathrm{FDG}$-avid metastatic DTC lesions are usually resistant to ${ }^{131} \mid$ treatment [17].

Neck ultrasonography plays an important role in the follow-up of patients with DTC. Stimulated Tg measurements and neck ultrasonography (US) provide the best sensitive and specific combination for identifying DTC patients with persistent or recurrent disease $[\mathbf{1 , 1 8 ]}$.

Serum Tg measurement is the most important component of follow-up. Tg is a thyroid-specific protein which is the precursor element of thyroid hormone biosynthesis [19]. It is secreted from either normal thyroid tissue or functioning malignant cells of DTC. Because of the thyroid is the only source of $\mathrm{Tg}$, a rise in its level in patients after thyroidectomy and radioiodine ablation indicates the recurrence of DTC. Sensitivity of $\mathrm{Tg}$ is limited in the presence of anti-Tg antibodies and serum heterophile antibodies (HAB). In the presence of anti-Tg antibodies, levels of $\mathrm{Tg}$ can be mistakenly low. AntiTg antibodies are detected in approximately $20 \%$ of patients with DTC, compared with the $10 \%$ incidence reported for the general population $[\mathbf{2 0 , 2 1 ]}$. Anti-Tg antibody concentrations typically fall to undetectable levels in a median of 3 years after a succesful treatment [22]. HAB leads to a false elevation in serum $\mathrm{Tg}$ levels. Preissner et al., found that $\mathrm{HAB}$ interference caused false $\mathrm{Tg}$ elevations in up to $3 \%$ of their patients. $\mathrm{HAB}$ interference should be suspected when Tg levels do not match the clinical findings [23].

In fact, stimulated Tg measurement is more sensitive than the basal Tg measurement [7]. Basal Tg measurement using high-sensitive assays proved to be effective [8]. Serum Tg assay sensitivity has greatly improved in the last decades, lowering the analytical sensitivity from $0.8 \mathrm{ng} / \mathrm{ml}$ to $0.01 \mathrm{ng} / \mathrm{ml}[\mathbf{2 4 , 2 5 ]}$. By using high-sensitive Tg assays, few patients with undetectable basal $\mathrm{Tg}$ had a $\mathrm{Tg}$ response higher than $2 \mathrm{ng} / \mathrm{ml}$ to $\mathrm{rhTSH}$ stimulation $[26,27]$. Some recent studies recommend that a $\mathrm{Tg}$ assay with a functional sensitivity of $0.1 \mathrm{ng} / \mathrm{ml}$ may reduce the need to perform stimulated Tg measurements [2,26-32].

Smallridge et al., showed that a basal $\mathrm{Tg}<0.1 \mathrm{ng} / \mathrm{ml}$ was highly predictive for a stimulated $\mathrm{Tg}<2 \mathrm{ng} / \mathrm{ml}$, thus eliminating the necessity for use of recombinant TSH in a large number of patients [26]. Malandrino et al., using an assay with a functional 
Kalender et al. Internal Medicine Inside 2013,

sensitivity of $0.1 \mathrm{ng} / \mathrm{ml}$, reported that only 5 (1.4\%) of the 356 patients with basal $\mathrm{Tg}$ levels no higher than $0.15 \mathrm{ng} / \mathrm{ml}$ had stimulated Tg levels higher than $2 \mathrm{ng} / \mathrm{ml}$ and none of them had recurrences on the follow-up [31]. In contrast, 33 of 69 with a basal $\mathrm{Tg}>0.15 \mathrm{ng} / \mathrm{ml}$ had recurrences. Spencer et al., found that only $0.3 \%$ of 655 patients with basal $\mathrm{Tg}<0.1 \mathrm{had}$ a stimulated $\mathrm{Tg}>2 \mathrm{ng} / \mathrm{ml}$, by using a sensitive Tg assay [32].

\section{Conclusion}

In our study, we found that 159 patients with undetectable basal Tg level, had a stimulated Tg level under $2 \mathrm{ng} / \mathrm{ml}$ and $142(89.3 \%)$ of them had an undetectable stimulated Tg level. In conclusion our data suggest that stimulated Tg level measurements may be avoided in DTC patients with undetectable basal Tg levels. Thus, unnecessary Tg stimulation with rhTSH or endogen TSH, diagnostic procedures (DWBS) and radiation exposure can be reduced.

\section{Competing interests}

The authors declare that they have no competing interests.

\section{Publication history}

Editor: Umid Kumar Shrestha, Manipal College of Medical Sciences, Nepal.

Received: 23-Apr-2013 Revised: 30-May-2013

Accepted: 10-Jun-2013 Published: 17-Jun-2013

\section{References}

1. Pacini F, Molinaro E, Castagna MG, Agate L, Elisei R, Ceccarelli C, Lippi F, Taddei D, Grasso L and Pinchera A: Recombinant human thyrotropinstimulated serum thyroglobulin combined with neck ultrasonography has the highest sensitivity in monitoring differentiated thyroid carcinoma. J Clin Endocrinol Metab 2003, 88:3668-73. | Article | PubMed

2. Cooper DS, Doherty GM, Haugen BR, Kloos RT, Lee SL, Mandel SJ, Mazzaferri EL, Mclver B, Pacini F, Schlumberger M, Sherman SI, Steward DL and Tuttle RM: Revised American Thyroid Association management guidelines for patients with thyroid nodules and differentiated thyroid cancer. Thyroid 2009, 19:1167-214. | Article | PubMed

3. Pacini F, Cetani F, Miccoli P, Mancusi F, Ceccarelli C, Lippi F, Martino E and Pinchera A: Outcome of $\mathbf{3 0 9}$ patients with metastatic differentiated thyroid carcinoma treated with radioiodine. World J Surg 1994, 18:6004. | Article | PubMed

4. Mazzaferri EL and Kloos RT: Clinical review 128: Current approaches to primary therapy for papillary and follicular thyroid cancer. J Clin Endocrinol Metab 2001, 86:1447-63. | Article | PubMed

5. Mazzaferri EL: NCCN thyroid carcinoma practice guidelines. Oncology. 1999, 13:391-442. I Website

6. Schlumberger MJ: Papillary and follicular thyroid carcinoma. $N$ Engl $\mathrm{J}$ Med 1998, 338:297-306. | Article | PubMed

7. Haugen BR, Pacini F, Reiners C, Schlumberger M, Ladenson PW, Sherman SI, Cooper DS, Graham KE, Braverman LE, Skarulis MC, Davies TF, DeGroot LJ, Mazzaferri EL, Daniels GH, Ross DS, Luster M, Samuels MH, Becker DV, Maxon HR, 3rd, Cavalieri RR, Spencer CA, McEllin K, Weintraub BD and Ridgway EC: A comparison of recombinant human thyrotropin and thyroid hormone withdrawal for the detection of thyroid remnant or cancer. J Clin Endocrinol Metab 1999, 84:3877-85. Article | PubMed

8. Rosario PW, Borges MA, Fagundes TA, Franco AC and Purisch S: Is stimulation of thyroglobulin $(\mathrm{Tg})$ useful in low-risk patients with thyroid carcinoma and undetectable Tg on thyroxin and negative neck ultrasound? Clin Endocrinol (Oxf) 2005, 62:121-5. | Article | PubMed
9. Schlumberger $M$ and Baudin $E$ : Serum thyroglobulin determination in the follow-up of patients with differentiated thyroid carcinoma. Eur J Endocrinol 1998, 138:249-52. | Article | PubMed

10. Cailleux AF, Baudin E, Travagli JP, Ricard M and Schlumberger M: Is diagnostic iodine-131 scanning useful after total thyroid ablation for differentiated thyroid cancer? J Clin Endocrinol Metab 2000, 85:175-8. | Article | PubMed

11. Huang SH, Wang PW, Huang YE, Chou FF, Liu RT, Tung SC, Chen JF, Kuo MC, Hsieh JR and Hsieh HH: Sequential follow-up of serum thyroglobulin and whole body scan in thyroid cancer patients without initial metastasis. Thyroid 2006, 16:1273-8. | Article | PubMed

12. Taylor H, Hyer S, Vini L, Pratt B, Cook G and Harmer C: Diagnostic 131 whole body scanning after thyroidectomy and ablation for differentiated thyroid cancer. Eur J Endocrinol 2004, 150:649-53. I Article I PubMed

13. Pacini F, Agate L, Elisei R, Capezzone M, Ceccarelli C, Lippi F, Molinaro $E$ and Pinchera A: Outcome of differentiated thyroid cancer with detectable serum $\mathrm{Tg}$ and negative diagnostic (131)I whole body scan: comparison of patients treated with high (131)I activities versus untreated patients. J Clin Endocrinol Metab 2001, 86:4092-7. | Article | PubMed

14. Schlumberger M, Mancusi F, Baudin E and Pacini F: 131I therapy for elevated thyroglobulin levels. Thyroid 1997, 7:273-6. | Article | PubMed

15. Lind P, Kresnik E, Kumnig G, Gallowitsch HJ, Igerc I, Matschnig S and Gomez I: 18F-FDG-PET in the follow-up of thyroid cancer. Acta Med Austriaca 2003, 30:17-21. | Article | PubMed

16. Helal BO, Merlet $P$, Toubert ME, Franc B, Schvartz C, GauthierKoelesnikov H, Prigent A and Syrota A: Clinical impact of (18)F-FDG PET in thyroid carcinoma patients with elevated thyroglobulin levels and negative (131)I scanning results after therapy. J Nucl Med 2001, 42:1464-9. | Article | PubMed

17. Wang W, Larson SM, Tuttle RM, Kalaigian H, Kolbert K, Sonenberg M and Robbins RJ: Resistance of [18f]-fluorodeoxyglucose-avid metastatic thyroid cancer lesions to treatment with high-dose radioactive iodine. Thyroid 2001, 11:1169-75. | Article | PubMed

18. Mazzaferri EL and Kloos RT: Is diagnostic iodine-131 scanning with recombinant human TSH useful in the follow-up of differentiated thyroid cancer after thyroid ablation? J Clin Endocrinol Metab 2002, 87:1490-8. | Article | PubMed

19. Low TH, Delbridge L, Sidhu S, Learoyd D, Robinson B, Roach P and Sywak $M$ : Lymph node status influences follow-up thyroglobulin levels in papillary thyroid cancer. Ann Surg Oncol 2008, 15:2827-32. | Article | PubMed

20. Kim ES, Lim DJ, Baek KH, Lee JM, Kim MK, Kwon HS, Song KH, Kang MI, Cha BY, Lee KW and Son HY: Thyroglobulin antibody is associated with increased cancer risk in thyroid nodules. Thyroid 2010, 20:885-91. | Article | PubMed

21. Spencer C, Petrovic I and Fatemi S: Current thyroglobulin autoantibody ( $\operatorname{TgAb}$ ) assays often fail to detect interfering $\operatorname{TgAb}$ that can result in the reporting of falsely low/undetectable serum Tg IMA values for patients with differentiated thyroid cancer. J Clin Endocrinol Metab 2011, 96:1283-91. | Article | PubMed

22. Grebe SK: Thyroglobulin autoantibodies, thyroid nodules, and new insights into some old questions. Thyroid 2010, 20:841-2. | Article | PubMed

23. Preissner CM, O'Kane DJ, Singh RJ, Morris JC and Grebe SK: Phantoms in the assay tube: heterophile antibody interferences in serum thyroglobulin assays. J Clin Endocrinol Metab 2003, 88:3069-74. | Article I PubMed

24. Van Herle AJ, Uller RP, Matthews NI and Brown J: Radioimmunoassay for measurement of thyroglobulin in human serum. J Clin Invest 1973, 52:1320-7. | Article | PubMed Abstract | PubMed Full Text

25. lervasi A, lervasi G, Bottoni A, Boni G, Annicchiarico C, Di Cecco P and Zucchelli GC: Diagnostic performance of a new highly sensitive thyroglobulin immunoassay. J Endocrinol 2004, 182:287-94. | Article | PubMed 
Kalender et al. Internal Medicine Inside 2013,

http://www.hoajonline.com/journals/pdf/2052-6954-1-5.pdf

26. Smallridge RC, Meek SE, Morgan MA, Gates GS, Fox TP, Grebe $S$ and Fatourechi V: Monitoring thyroglobulin in a sensitive immunoassay has comparable sensitivity to recombinant human tsh-stimulated thyroglobulin in follow-up of thyroid cancer patients. I Clin Endocrinol Metab 2007, 92:82-7. | Article | PubMed

27. lervasi A, lervasi G, Ferdeghini M, Solimeo C, Bottoni A, Rossi L, Colato $C$ and Zucchelli GC: Clinical relevance of highly sensitive Tg assay in monitoring patients treated for differentiated thyroid cancer. Clin Endocrinol (Oxf) 2007, 67:434-41. | Article | PubMed

28. Rosario PW and Purisch S: Does a highly sensitive thyroglobulin ( $\mathrm{Tg}$ ) assay change the clinical management of low-risk patients with thyroid cancer with $\mathrm{Tg}$ on $\mathrm{T} 4<1 \mathrm{ng} / \mathrm{ml}$ determined by traditional assays? Clin Endocrinol (Oxf) 2008, 68:338-42. | Article | PubMed

29. Schlumberger M, Hitzel A, Toubert ME, Corone C, Troalen F, Schlageter $\mathrm{MH}$, Claustrat F, Koscielny S, Taieb D and Toubeau M et al.: Comparison of seven serum thyroglobulin assays in the follow-up of papillary and follicular thyroid cancer patients. J Clin Endocrinol Metab 2007, 92:248795. | Article | PubMed

30. Zophel K, Wunderlich G and Smith BR: Serum thyroglobulin measurements with a high sensitivity enzyme-linked immunosorbent assay: is there a clinical benefit in patients with differentiated thyroid carcinoma? Thyroid 2003, 13:861-5. | Article | PubMed

31. Malandrino P, Latina A, Marescalco S, Spadaro A, Regalbuto C, Fulco RA, Scollo C, Vigneri R and Pellegriti G: Risk-adapted management of differentiated thyroid cancer assessed by a sensitive measurement of basal serum thyroglobulin. J Clin Endocrinol Metab 2011, 96:1703-9. | Article | PubMed

32. Spencer C, Fatemi S, Singer P, Nicoloff J and Lopresti J: Serum Basal thyroglobulin measured by a second-generation assay correlates with the recombinant human thyrotropin-stimulated thyroglobulin response in patients treated for differentiated thyroid cancer. Thyroid 2010, 20:587-95. | Article | PubMed

\section{Citation:}

Kalender E, Elboga U, Celen YZ, Demir HD, Sahin E, Karaçavuş S, Basibuyuk M and Yilmaz M: Stimulated tg level measurements may be avoided in differentiated thyroid carcinoma patients who have undetectable basal tg levels. Internal Medicine Inside 2013, 1:5. http://dx.doi.org/10.7243/2052-6954-1-5 